\title{
Research on the Relationship between Corporate Governance and Firm Performance: Empirical Evidence from Companies Listed on the Stock Exchange in Vietnam
}

\author{
Trang Thi Kieu Pham \\ Tan Trao University, Tuyen Quang, Vietnam
}

\begin{abstract}
:
This study examines the effect of corporate governance on firm performance measure as ROA and Tobin's Q of listed companies in Vietnam. Data samples were collected from 189 companies for Fiscal years 2011 - 2014. Fixed-effects and Random-effects models were estimated to evaluate the impact of corporate governance on firm performance. The study found evidence that some characteristics of corporate governance such as CEO duality, board size and women on board have a negative influence on firm performance as measured by ROA and Tobin's Q. By contrast, independent audit committee members, ownership of governance, ownership of foreign institutional investors and ownership of domestic institutional investors have a positive impact on these two performance measures of firms. The study also revealed a positive impact of ownership of managers on firm performance measured by ROA, however, in the case of Tobin's Q there is no significant correlation.
\end{abstract}

Paper Type: Research paper

Keywords: Corporate Governance; Firm performance; Vietnam; CEO Duality, Ownership Structure, Gender, Firm Size, Financial Leverage, Inflation 


\section{Introduction}

Corporate governance is typically seen as an important mechanism by which corporations are monitored, controlled, and directed. Corporate scandals in many different countries have maintained both public and political interest in corporate governance, especially in countries with a weak legal framework (Klapper and Love, 2004). However, previous studies often show conflicting results regarding the impact of corporate governance on firm performance (e.g. Cheng, 2008; Christensen et al., 2010; Pham et al., 2011). In Vietnam, the concerns and discussions on the relationship between corporate governance and firm performance has been a new issue. There were several research studies examine the effect of corporate governance on firm performances; however, these research results are quite dissimilar (e.g. Dao and Hoang, 2014; Vo and Nguyen, 2014).

In this paper, the author continues with an earlier study conducted Pham in 2016, titled "The relationship between corporate governance and the performance of the firm: a literature review with a focus on the Vietnamese enterprises". The author consider some elements of corporate governance, namely, the duality of CEO, the size of the board, the presence of female board members, the presence of independent audit committee members and the ownership of institutional investor. The result of the current study will contribute to the existing knowledge relating to corporate governance practices on firm performance of Vietnamese publicly traded companies. It will also provide management with useful knowledge on corporate governance mechanisms which affect the firm performance in Vietnam.

This paper is comprised of the following sections: Section 1 provides an introduction. Section 2 reviews the prior empirical literature on corporate governance and firm performance. The research hypotheses are developed in section 3. The data and methodology are described in section 4. The next section discusses empirical results. Finally, the last section concludes the study with main findings.

\section{Literature Review}

\subsection{The duality of CEO (the Chief Executive Officer also holds the position of the Chairman of the Board) and firm performance}

According to agency theory, CEO duality is bad for firm performance due to a compromise between the monitoring and control of the CEO since CEO duality may hinder the ability of board to monitor management and hence raise the agency cost (Jensen and Meckling 1976; Fama and Jensen 1983). Yermack (1996) suggests that a company is more valuable when CEO and chairman positions are held by different persons. Similarly, Fosberg (2004) found that firms with the separation of the CEO and Chairman position are likely to employ the optimal amount of debt in their capital.

Contrary to agency theory, stewardship theory shows that CEO duality would improve company performance given that CEO duality can monitor the company unambiguously and can also have a unique command throughout the company (Adams et al, 2005; Davis et al, 1997). A firm with the two positions held by one person would avoid confusion among managers, employees, and other stakeholders and also

International Journal of Management and Applied Research, 2016, Vol. 3, No. 4 
facilitate more effective and quicker decision-making (Finkelstein and D'Aveni, 1994). Faleye (2007) indicates that CEO duality is positively associated with CEO reputation, managerial ownership, and organizational complexity.

However, empirical studies examining the relationship between CEO duality and corporate performance has produced conflicting results. The study of Baliga et al. (1996) shows that there is no significant difference in firm performance when the duality status changes and there is also no significant difference in the effect of duality and non-duality on performance. By contrast, Elsayed (2007) concluded that the impact of CEO duality on firm performance vary across industries, moreover, CEO duality attracts a positive and significant coefficient in the cases where corporate performance is low.

\section{2. The size of the board and firm performance}

Dalton et al $(1999,2005)$ mention that one of the advantages of large board size is to enable the board to collect a wealth amount of information, which subsequently enhance firm performance. However, it is evident that small board size is more effective at monitoring top managers than large board size because a small board reduces coordination cost and free rider problems, and therefore it leads to high performance (Lipton and Lorsch, 1992; Jensen, 1993; Yermack, 1996). However, some researchers found that there is a negative relationship between board size and firm performance (e.g. Cheng, 2008) while some scholars concluded that the relationship between corporate governance and performance measures is insignificant (Pham et al., 2011) or conflicting (Christensen et al., 2010).

\section{3. The presence of female board members and firm performance}

Evidence suggests that board gender diversity may be associated with improved decision making, beneficial for governance, and ultimately, firm performance (e.g. Campbell and Mínguez-Vera, 2008; Jurkus et al., 2011; Smith et al., 2006). Smith et al. (2006) explain the importance of female representation on board as follows. Firstly, female board members have a better understanding of market place of the firm, and hence this increases creativity and innovation. Ssecondly, female board members may improve image of the firm and this will have a positive effects on firm performance. Moreover, empirical studies (Campbell and Mínguez-Vera, 2008; Jurkus et al., 2011) have found evidence that gender diversity enhances firm performance. However, several research studies have found a negative, or in some case insignificant, influence of female representation on board and firm performance (Larcker et al., 2007; Adams and Ferreira, 2009; Gregory-Smith et al., 2014).

\section{4. The presence of independent audit committee members and firm performance}

The audit committee plays a key role in supervising and monitoring management activities to protect the interest of shareholders. Independent directors with financial expertise are often seen as valuable resources in providing guidance and oversight of a firm's financial reporting practices (Agrawal and Chadha, 2005). Aldamen et al. (2013) indicate that audit committee independence monitors management activities effectively because such committees are more likely to make objective decisions without negotiation and deliberation. Similarly, Erickson et al. (2005) conclude that independent members may minimize agency problems which therefore leads to the

International Journal of Management and Applied Research, 2016, Vol. 3, No. 4 
improvement of firm performance. A number of studies explored the impact of independent audit committee members on firm performance and these concluded that there is a positive connection between audit committee independence and firm performance (e.g. Aldamen et al., 2013; Ghabayen, 2012).

\subsection{The ownership of institutional investor and firm performance}

Institutional shareholders and ownership structure play an important role in determining whether appointed managers expropriate minority shareholders (Lemmon and Lins, 2003). It is perceived that investors with large ownership have strong interest in maximising a firm's value in pursuing their financial goals. Subsequently, the large shareholders have incentive and power to enforce managers to act in accordance with the value maximization goal of the company (Lemmon and Lins, 2003; Shleifer and Vishny, 1997). As Shleifer and Vishny (1997: 754) state: "Large shareholders thus address the agency problem in that they have both a general interest in profit maximization, and enough control over the assets of the firm to have their interest respected". Similarly, Bethel et al (1998) point out that institutional shareholders bring out an increase in share value and the rate of top management turnover.

\section{Hypothesis Development}

With respect to the above literature review, it is suggested that there are mixed findings on some characteristics applied to corporate governance, as follows: CEO duality, board size, female board members, independent audit committee members, institutional investor ownership.

In the Vietnamese context, most firms are owned by family, therefore, the firm may improve its performance and the interest of the manager and shareholders will be aligned if the CEO and chairman positions are occupied by one person. Futhermore, such family controlled firms are small- and of medium-size, hence, CEO duality may help the company save the cost of hiring an outside director. As such, the study hypothesis is developed as below:

\section{H1: There is a positive relationship between CEO duality and firm performance.}

As mention above, most of listed companies on Vietnam's stock market are small and medium sized enterprises with low foreign investment and low management standard. Therefore, it is assumed that a large board increases communication problems and brings less efficient decision making. As a result firm performance declines. The following hypothesis is considered to test the relationship between board size and firm performance:

\section{H2: There is a negative relationship between board size and firm performance}

There is no legislation regulating the proportion of women on the boards of directors of firms in Vietnam. However, with a trend toward increasing the number of women on boards and robust evidence of a positive impact of women board members on firm performance, the study develops the hypothesis as below:

International Journal of Management and Applied Research, 2016, Vol. 3, No. 4 
H3: There is a positive relationship between female board members and firm performance

With regard to the audit committee, independence is essential to the effectiveness of a firm's internal audit committee. The audit committee provides consulting services for the firm's issues related to special investigations, internal controls, and other fields of interest and concern. Hence, if the audit committee members are not independent, i.e. they hold concurrently two positions in the company, they are likely to make biased decisions. This is because they afraid that their decision may affect their second job, or may make their managers hostile toward them. Personal enmity is easily brought into the work place, so employees do not want to make their manager uncomfortable with them. Consequently, the hypothesis is developed as follows:

H4: There is a positive relationship between independent audit committee members and firm performance

Over the last decade, the integration process expressed by Vietnamese companies has been accompanied by the increase of foreign investors and institutional investors who hold at least $5 \%$ of a firm's outstanding shares. According to the survey carried out by the IFC, the GCGF and Vietnam's SSC (2011), it is recommended that institutional investors should, wherever possible, incorporate demands of companies for good corporate governance implementation. Further, the OECD reports that institutional investors play an important role in promoting good corporate governance.

In this study, the ownership of institutional investors is categorised as follows: ownership of government, ownership of foreign institutional investors, ownership of domestic institutional investors, and ownership of managers. The following hypotheses are formulated to test the relationship between institutional investors and firm performance:

H5a: There is a positive correlation between ownership of government and firm performance.

H5b: There is a positive correlation between ownership of foreign institutional investors and firm performance.

H5c: There is a positive correlation between ownership of domestic institutional investors and firm performance

H5d: There is a positive correlation between ownership of managers and firm performance

\section{Data and Methodology}

This study uses CEO duality status, board composition, audit committee, ownership of institutional investors, financial ratios from annual reports and audited financial statements of companies which are listed on the Hochiminh stock exchange (HOSE) and the Hanoi stock exchange (HNX) for the period from 2011 to 2014. However,

International Journal of Management and Applied Research, 2016, Vol. 3, No. 4 
because of different capital structures and operation requirements, companies such as banks, other financial institutions and insurance institutions were not included, and 229 other companies were also excluded due to difficulties in collecting the relevant data. As a consequence, a sample of 359 Vietnamese listed companies was collected. According to Slovin's formula sampling techniques with 5\% error, the study was then taken of 187 listed firms with the total of 748 observations.

The variables include: independent variables (corporate governance); dependent variables (firm performance); and control variables. These variables were defined and measured in table 1 below

Table 1: Variable definitions and measurement

\begin{tabular}{|c|c|c|}
\hline Variables & Definition & Measurement \\
\hline \multicolumn{3}{|c|}{ Independent variables } \\
\hline DUAL & CEO duality & $\begin{array}{l}\text { Coded " } 1 \text { " if CEO holds the position of } \\
\text { Chairman, and " } 0 \text { " otherwise }\end{array}$ \\
\hline SIZE & Board size & $\begin{array}{l}\text { Number of members on board of } \\
\text { directors }\end{array}$ \\
\hline GENDER & Female board members & Number of women on board \\
\hline INDEP & $\begin{array}{l}\text { Independent audit committee } \\
\text { members }\end{array}$ & $\begin{array}{l}\text { Number of independent members in } \\
\text { audit committees }\end{array}$ \\
\hline OWN_GOV & Ownership of government & Share percentage of Government \\
\hline OWN_INTER & $\begin{array}{l}\text { Ownership of foreign institutional } \\
\text { investors }\end{array}$ & $\begin{array}{l}\text { Share percentage of foreign institutional } \\
\text { investors }\end{array}$ \\
\hline OWN-PRIVA & $\begin{array}{l}\text { ownership of domestic } \\
\text { institutional investors }\end{array}$ & $\begin{array}{l}\text { Share percentage of domestic } \\
\text { institutional investors }\end{array}$ \\
\hline OWN_MAN & ownership of managers & Share percentage of mangers \\
\hline \multicolumn{3}{|c|}{ Dependent variables } \\
\hline ROA & Return on asset & $\begin{array}{l}\text { Earning after tax divided by total assets } \\
\text { (Total assets }+ \text { market value of equity - }\end{array}$ \\
\hline Tobin's Q & Tobin's Q & $\begin{array}{l}\text { book value of equity - deferred taxes)/ } \\
\text { total assets }\end{array}$ \\
\hline \multicolumn{3}{|c|}{ Control variables } \\
\hline FIRMSIZE & Firm size & Total assets \\
\hline LEVER & Financial leverage & $\begin{array}{l}\text { Ratio of total debt divided by total assets } \\
\text { Coded "1" if a company publishes data }\end{array}$ \\
\hline INFLATION & Inflation & $\begin{array}{l}\text { showing the inflation rate over } 12 \% \text { for } \\
\text { any year of the study, and " } 0 \text { " otherwise }\end{array}$ \\
\hline
\end{tabular}

A panel data regression method was used in this study. After diagnostic tests, it was found that the Random Effects Model supported the data in the case of ROA as the dependent variable. The Fixed Effects Model also supported the data in the case of Tobin's $\mathrm{Q}$ as the dependent variable.

International Journal of Management and Applied Research, 2016, Vol. 3, No. 4 


\section{Results and Discussion}

Table 2: Descriptive statistics

\begin{tabular}{lcccccc}
\hline & N-Obs & Minimum & Maximum & \multicolumn{2}{c}{ Mean } & $\begin{array}{c}\text { Std. } \\
\text { Deviation } \\
\text { Statistic }\end{array}$ \\
\hline ROA & Statistic & Statistic & Statistic & Statistic & Std. Error & St8 \\
Tobin's Q & 748 & 0.657 & 0.588 & 0.055 & 0.003 & 0.086 \\
DUAL & 748 & 0.000 & 1.000 & 0.410 & 0.018 & 0.492 \\
SIZE & 748 & 3.000 & 11.000 & 5.520 & 0.043 & 1.181 \\
GENDER & 748 & 0.000 & 3.000 & 0.830 & 0.031 & 0.858 \\
INDEP & 748 & 0.000 & 5.000 & 3.060 & 0.019 & 0.517 \\
OWN_GOV & 748 & 0.000 & 87.380 & 23.788 & 0.917 & 25.093 \\
OWN_INTER & 748 & 0.000 & 78.000 & 3.127 & 0.340 & 9.303 \\
OWN_PRIVA & 748 & 0.000 & 86.580 & 19.280 & 0.770 & 21.059 \\
OWN_MAN & 748 & 0.000 & 60.515 & 7.544 & 0.423 & 11.556 \\
FIRMSIZE & 748 & 11.666 & 36368.864 & 1372.640 & 124.000 & 3391.447 \\
LEVER & 748 & 0.008 & 0.957 & 0.494 & 0.008 & 0.222 \\
INFLATION & 748 & 0.000 & 1.000 & 0.250 & 0.016 & 0.433 \\
\hline
\end{tabular}

Table 2 shows that the average Tobin's Q of 0.95 with a standard deviation of 0.312 . ROA has a wide range from a minimum value of $-65.7 \%$ to a maximum value of $58.8 \%$ with a mean of $5.5 \%$. The average board has 5.52 directors and has a wide range from 3 to 11 directors. However, the number of women on boards is quite low with an average value of 0.83 directors. The mean value for the independent audit committee members is 3.06 with a standard deviation of 0.517 . In general, the ownership of government and the ownership of domestic institutional investors have mean values of $23.78 \%$ and $19.28 \%$ respectively, and this is significantly higher than the ownership of foreign institutional investors and the ownership of managers, namely $3.12 \%$ and $7.54 \%$.

Table 3 shows the correlation among independent variables and control variables. It is noted that there is no significant relation among independent variables and control variables. The variables with the highest correlation are Dual and Level $(\mathrm{P}=-0.70)$. Therefore, all the variables will be used for regression.

International Journal of Management and Applied Research, 2016, Vol. 3, No. 4 
Research on the Relationship between corporate governance and firm performance: Empirical evidence from companies listed on the stock exchange in Vietnam

Table 3: Correlation Matrix

\begin{tabular}{|c|c|c|c|c|c|c|c|c|c|c|c|}
\hline & 1 & 2 & 3 & 4 & 5 & 6 & 7 & 8 & 9 & 10 & 11 \\
\hline 1. CEO Duality & 1 & -0.48 & 0.39 & 0.43 & 0.30 & 0.44 & 0.51 & 0.65 & -0.05 & -0.70 & -0.61 \\
\hline 2. Board Size & -0.48 & 1 & 0.10 & 0.34 & -0.17 & 0.16 & 0.02 & 0.05 & 0.38 & 0.03 & 0.02 \\
\hline 3. Gender & 0.39 & 0.10 & 1 & 0.02 & -0.14 & 0.14 & 0.09 & 0.05 & -0.04 & -0.06 & -0.02 \\
\hline $\begin{array}{l}\text { 4. Independent audit } \\
\text { committee members }\end{array}$ & 0.43 & 0.34 & 0.02 & 1 & 0.08 & 0.08 & -0.03 & -0.06 & 0.17 & 0.05 & -0.03 \\
\hline $\begin{array}{l}\text { 5. Ownership of } \\
\text { government }\end{array}$ & 0.30 & -0.17 & -0.14 & 0.08 & 1 & $-0.143-$ & -0.366 & -0.319 & -0.073 & -0.04 & 0.000 \\
\hline $\begin{array}{l}\text { 6. Ownership of } \\
\text { foreign institutional } \\
\text { investors }\end{array}$ & 0.44 & 0.16 & 0.14 & 0.08 & -0.143 & 1 & -0.022 & -0.094 & 0.144 & -0.095 & -0.059 \\
\hline $\begin{array}{l}\text { 7. Ownership of } \\
\text { managers }\end{array}$ & 0.51 & 0.02 & 0.09 & -0.03 & -0.366 & -0.022 & 1 & 0.456 & 0.003 & $0.10^{2}$ & -0.040 \\
\hline $\begin{array}{l}\text { 8. Ownership of } \\
\text { domestic institutional } \\
\text { investors }\end{array}$ & 0.65 & 0.05 & 0.05 & -0.06 & -0.319 & -0.094( & 0.456 & 1 & 0.092 & 0.090 & 0.054 \\
\hline 9. Firm Size & -0.05 & 0.38 & -0.04 & 0.17 & -0.073 & 0.144 & 0.003 & 0.092 & 1 & 0.370 & 0.027 \\
\hline 10. Financial & -0.70 & 0.03 & -0.06 & 0.05 & -0.046 & -0.095( & 0.104 & 0.090 & 0.370 & 1 & 0.002 \\
\hline 11. Inflation & -0.61 & 0.02 & -0.02 & -0.03 & 0.000 & $-0.059-$ & -0.040 & -0.054 & -0.027 & 0.002 & $\mathbf{1}$ \\
\hline
\end{tabular}

The results of the relation between corporate governance and firm performance measured by ROA are presented in Table 4 .

Table 4: Panel estimation of corporate governance with ROA as the dependent variable (REM)

\begin{tabular}{lccc}
\hline \multicolumn{1}{c}{ Variables } & Coefficient $(\boldsymbol{\beta})$ & Stand.Error $(\mathbf{S E})$ & T-value \\
\hline CEO Duality & -0.0137 & 0.0062 & $-2.194^{(* *)}$ \\
Board Size & -0.0020 & 0.0004 & $-5.583^{(* * *)}$ \\
Gender & -0.0010 & 0.0001 & $-9.257^{(* * *)}$ \\
Independent audit committee members & 0.0075 & 0.0030 & $2.503^{(* *)}$ \\
Ownership of government & 0.0006 & 0.0002 & $2.924^{(* *)}$ \\
Ownership of foreign institutional investors & 0.0015 & 0.0004 & $3.759^{(* * *)}$ \\
Ownership of managers & 0.0004 & 0.0001 & $3.258^{(* * *)}$ \\
Ownership of domestic institutional investors & 0.0023 & 0.0002 & $10.898^{(* * *)}$ \\
Firm Size & 0.0099 & 0.0034 & $2.899^{(* * *)}$ \\
Financial Leverage & -0.1441 & 0.0202 & $-7.150^{(* * *)}$ \\
Inflation & -0.0162 & 0.0044 & $-3.711^{(* * *)}$ \\
C & -0.1378 & 0.0558 & $-2.472^{(* *)}$ \\
\hline
\end{tabular}

Note: $(* * *)$ significance at $1 \%,(* *)$ significance at $5 \%,(*)$ significant at $10 \%$

International Journal of Management and Applied Research, 2016, Vol. 3, No. 4 
Similar to the result from REM for ROA, FEM for Tobin's Q also found there is a significant negative effect of CEO duality, board size and female board members on Tobin's $\mathrm{Q}$ with $\beta$-coefficient of $-0.0063,-0.0115,-0.0065$ respectively, and $\mathrm{p}$-value are almost zero at $95 \%$ confidence limit.

In addition, the result also reveals a significant positive impact of independent audit committee members, ownership of governance, ownership of foreign institutional investors, and ownership of domestic institutional investors on Tobin's Q with p-value $<5 \%$. Nevertheless, ownership of managers doesn't exhibit any impact on Tobin's Q.

Regarding control variables, leverage and inflation show a negative and significant effect on Tobin's Q, while there is no significant impact of firm size on Tobin's Q.

In summary, the coefficients on CEO duality are negatively and statistically significant for two firm performance measures (ROA and Tobin's Q). Hence Hypothesis 1 is rejected. Similarly, the coefficients on female board members are also negatively and statistically significant for two firm performance measures. As a result, Hyphothesis 3 is rejected. Apart from that, there is also a significant negative impact of board size on firm performance in both cases of ROA and Tobin's Q. Therefore, Hypothesis 2 is supported.

By contrast, the results suggest that independent audit committee members, ownership of government, ownership of foreign institutional investors, and ownership of domestic institutional investors have a statistically significant positive influence on both the two dependent variables (ROA and Tobin's Q). However, the coefficient on ownership of managers is only positively and statistically significant for firm performance measured by ROA, while it doesn't show any impact on firm performance measured by Tobin's Q. Consequently, Hypotheses 4, 5a, 5b, 5c are accepted in both cases of ROA and Tobin's Q. Hypothesis 5d is only accepted in the case of ROA as the dependent variable and rejected in the case of Tobin's $Q$ as the dependent variable.

\section{Conclusion}

The research paper was conducted to examine the effect of corporate governance on firm performance measuring factors such as ROA and Tobin's Q. With the major focus on Vietnamese economy, the data was collected from firms listed in HOSE and HNX, Vietnam. The main findings of this study suggest that CEO duality, board size, and women on board negatively affect firm performance. Conversely, the presence of independent audit committee members is positively related to firm performance. In addition, most ownership of institutional investor is associated with firm performance improvement. Only in the case of Tobin's Q as a measure of firm performance, there is no evidence relationship between manager's ownership and firm performance.

As a consequence, the study supports the agency theory which confirms that the firm with split titles of CEO and chairman of the board will improve its performance. Regarding board size, the study provides empirical evidence consistent with the arguments of scholars who argue that small board size brings greater focus, participation, and offers fewer opportunities for free riding (Pham et al., 2011), and as

International Journal of Management and Applied Research, 2016, Vol. 3, No. 4 
a result, small board size leads to high performance. In addition, the study result shows that the presence of female board members will lead to a declining firm performance. By contrast, the presence of independent audit committee members will lead to the improvement of firm performance. Furthermore, the result of the study confirms that ownership of institutional investors is positively associated with firm performance. However, ownership of institutional investors, categorised as ownership of managers, has different effects on firm performance in different measures.

The findings presented in this research are limited by few elements of corporate governance being considered and the data being collected over a short time period. Hence, it is suggested that future study should be conducted with more elements of corporate governance and data being collected over longer time period.

\section{References}

1. Adams, R., Almeida, H., Ferreira, D, (2005), "Powerful CEOs and their Impact on corporate performance", Review of Financial Studies, Vol.18, No.4, pp. 14031432. https://doi.org/ 10.1093/rfs/hhi030

2. Adams, R.B., and Ferreira, D, (2009), "Women in the boardroom and their impact on governance and performance", Journal of Financial Economics, Vol. 94, No. 2, pp. 291-309. https://doi.org/10.1016/j.jfineco.2008.10.007

3. Agrawal, A. and Chadha, S. (2005), "Corporate Governance and Accounting Scandals", The Journal of Law \& Economics, Vol. 48, No. 2 pp. 371-406. https://doi.org/10.1086/430808

4. Aldamen, H., Ducan, K., Kelly, S., McNamara, R., Nagel, S, (2013), “Audit committee characteristics and firm performance during the global financial crisis", Accounting and Finance, Vol. 52, No. 4, pp.971-1000. https://doi.org/10.1111/j.1467-629X.2011.00447.x

5. Baliga, B., Moyer, R.C., and Rao, R.S, (1996), "CEO duality and firm performance what's the fuss". Strategic Management Journal, Vol.17, No.1, pp.41-53. http://www.jstor.org/stable/2486936

6. Bethel, J.E., Liebeskind, J.P., Opler, T, (1998), "Block share purchases and corporate performance", The Journal of Finance, Vol.53, No.2, pp.605-634. https://doi.org/10.1111/0022-1082.244195

7. Campbell, K. and Mínguez-Vera, A. (2008), "Gender Diversity in the Boardroom and Firm Financial Performance", Journal of Business Ethics, Vol. 83, No. 3, pp 435-451. https://doi.org/10.1007/s10551-007-9630-y

8. Cheng, S. (2008), "Board size and the variability of corporate performance", Journal of Financial Economics, Vol. 87, No. 1, pp. 157-176. https://doi.org/10.1016/j.jfineco.2006.10.006.

9. Christensen, J., Kent, P., and Stewart, J. (2010), "Corporate governance and company performance in Australia", Australian Accounting Review, Vol.55, pp.372-386. https://doi.org/10.1111/j.1835-2561.2010.00108.x

International Journal of Management and Applied Research, 2016, Vol. 3, No. 4 
10. Dao, T.B., and Hoang, T.H.G, (2014), VN30 Index: Corporate governance and performance analysis, https://doi.org/10.2139/ssrn.2543097

11. Dalton, D., Daily, C., Johnson, J. and Ellstrand, A. (1999), "Number of directors and financial performance: A meta-analysis", Academy of Management Journal, Vol. 42, No. 6, pp.674- 686. https://doi.org/10.2307/256988

12. Dalton, D. and Dalton, C. R. (2005), "Boards of directors: Utilizing empirical evidence in developing practical prescriptions", British Journal of Management, Vol.16, No. S1, pp.91-97. https://doi.org/10.1111/j.1467-8551.2005.00450.x

13. Davis, J.H., Schoorman, F.D., and Donaldson, L, (1997), "Toward a stewardship theory of management", The Academy of Management Review, Vol.22, No.1, pp. 20-47. https://doi.org/10.5465/AMR.1997.9707180258

14. Elsayed, K. (2007), “Does CEO Duality Really Affect Corporate Performance?”, Corporate Governance: An International Review, Vol. 15, No. 6, pp. 1203-1214. https://doi.org/j.1467-8683.2007.00641.x

15. Erickson, J., Park, Y., Reising, J., and Shin, H, (2005), "Board composition and firm value under concentrated ownership: the Canadian evidence", Pacific-Basin Finance Journal, Vol.13, No.4, pp.387-410

16. Faleye, O, (2007), "Does one hat fit all? The case of corporate leadership structure", Journal of Management and Governance, Vol.13, No.3, pp.239-259

17. Fama, E.F., and Jensen, M.C, (1983), "Separation of ownership and control", Journal of Law and Economics, Vol.26, No.2, pp.301-325

18. Finkelstein, R. D. andAveni, R.A, (1994), "CEO duality as a double -edged sword: how boards of directors balance entrenchment avoidance and unity of command", The Academy of Management Journal, Vol.37, No.5, pp. 1079-1108. https://doi.org/10.2307/256667

19. Fosberg, H., (2004), “Agency problems and debt financing: Leadership structure effects", Corporate Governance International Journal of Business in Society,Vol.4, No.1, pp.31-38. https://doi.org/10.1108/14720700410521943

20. Gregory-Smith, I., Main B.G.M., and O’Reilly, C.A., (2014), “Appointments, pay and performance in UK boardrooms by gender", The Economic Journal, Vol.124, No. 574, pp.109-128. https://doi.org/10.1111/ecoj.12102

21. Jensen, M.C., and Meckling, W.H, (1976), "Theory of the firm: Managerial behaviour, agency costs and ownership structure", Journal of Financial Economics, Vol.3, No.4, pp.305-360

22. Jensen, M. C. (1993) "The modern industrial revolution, exit, and the failure of internal control systems", Journal of Finance, Vol.48, No. 3, pp.831-880. https://doi.org/10.1111/j.1540-6261.1993.tb04022.x

23. Jurkus, A.F., Park, J.C., and Woodard L.S, (2011), "Women in top management and agency costs", Journal of Business Research, Vol.64, No.2, pp.180-186. https://doi.org/10.1016/j.jbusres.2009.12.010.

International Journal of Management and Applied Research, 2016, Vol. 3, No. 4 
24. Klapper, L. and Love, I. (2004), "Corporate governance, investor protection, and performance in emerging markets", Journal of Corporate Finance, Vol. 10, No. 5, pp. 703-728. https://doi.org/10.1016/S0929-1199(03)00046-4.

25. Larcker D., Richardson, S., Tuna, I., (2007), "Corporate governance, accounting outcomes, organizational performance", The Accounting Review, Vol.82, No.4, pp.963-1008. https://doi.org/10.2308/accr.2007.82.4.963

26. Lemmon, M. L. and Lins, K. V. (2003), “Ownership Structure, Corporate Governance, and Firm Value: Evidence from the East Asian Financial Crisis", The Journal of Finance, Vol. 58, No. 4, pp. 1445-1468. https://doi.org/10.1111/15406261.00573

27. Lipton, M. and Lorsch, J. W. (1992), “A modest proposal for improved corporate governance”, Business Lawyer, Vol.48, No. 1, pp.59- 77.

https://www.jstor.org/stable/40687360

28. Pham, P.K., Suchard, J., and Zein, J. (2011), "Corporate governance and alternative performance measures: Evidence form Australian firms", Australian Journal of Management, Vol. 36, No. 3, pp.371-386.

https://doi.org/10.1177/0312896211413035

29. Pham, T.K.T., (2016), "The relationship between corporate governance and the performance of the firm: a literature review with a focus on the Vietnamese enterprises", Proceedings of the 4th International Conference on Management, Leadership and Governance (ICMLG), Saint-Petersburg State University of Economics, Russia, 14-15 April 2016, pp.460-465.

30. Shleifer, A. and Vishny, R, (1997), “A survey of Corporate governance”, Journal of Finance, Vol. 52, No. 2, pp. 737-783. https://doi.org/10.1111/j.15406261.1997.tb04820.x

31. Smith, N., Smith, V. and Verner, M. (2006), "Do Women in Top Management Affect Firm Performance? A Panel Study of 2500 Danish Firms", International Journal of Productivity and Performance Management, Vol.55, No.7, pp.569-593. https://doi.org/10.1108/17410400610702160

32. Vo, H.D., and Nguyen, M.T, (2014), "The Impact of Corporate Governance on Firm Performance: Empirical Study in Vietnam”, International Journal of Economics and Finances, Vol. 6, No. 6, pp. 1-14. https://doi.org/10.5539/ijef.v6n6p1

33. Yermack, D, (1996), "Higher market valuation of companies with a small board of directors", Journal of Financial Economics, Vol.40, No.2, pp.185-211. https://doi.org/10.1016/0304-405X(95)00844-5 